\title{
Chapter 9 \\ The coup nobody noticed: the Solomon Islands Western State Movement in 2000
}

Ian Scales

The most significant political consequence of the conflict in Solomon Islands between 1998 and 2000 was the widespread shift in thinking towards a federal system of government. This chapter argues that long-held political aspirations for greater independence in the resource-rich Western Province were reactivated in a milieu of ethnic tension in the west, and that Western Province politicians used the visionless Malaitan coup in Honiara as a springboard for a calculated push towards their own enhanced fiscal autonomy through advocacy of a federal system. Although the west was the only region likely to increase its wealth from the kind of federalism reforms it proposed, most other provinces (after the collapse of the central government) adopted the west's well-articulated agenda. The outstanding success of the west in trumping all other parties, effectively gaining control of the negotiation on the redistribution of state power, and the lack of attention this drew, can only be admired. It was the coup nobody noticed.

Solomon Islands' political geography is inhabited by three heavyweight players: Malaita, Guadalcanal and Western Province. Popular commentary on the 1998-2000 armed conflict in Solomon Islands has understandably focused on the conflict over Guadalcanal land between groups associated with Malaita and Guadalcanal. This chapter takes a different focus, seeking to understand the outcome of a second, less bloody, conflict which erupted in the west and escaped international attention. This focus derives from first hand observation of events as they unfolded in the west during 1999-2000, when I was based on the Western Province island of Kolombangara. 
Conflict in the west, beginning in 1998, resonated initially with that on Guadalcanal by centring on local resentment of Malaitan settlement in the province, but it transformed in a way that did not occur in Guadalcanal. Direct conflict between Malaitan and western youths subsided as western political leaders set their sights on an overarching and long-desired goal: wresting control of resources from the national government. Politicians in the west sought to revitalise the old regional autonomy movement, which had been mostly dormant since Solomon Islands gained independence in 1978. Their focus on wealth was consistent with the prevailing policy discourse in Solomon Islands, which had always been about development. As early as 1893, a main justification for establishing the colonial protectorate- the first form of state in Solomon Islands - was the self-serving proposal that development would pay for the protectorate's administration (Heath 1974; Bennett 1987). After independence, successive national and provincial governments launched development plan after development plan, while political candidates for national constituency and provincial ward seats invariably campaigned on development as the main issue. For voters in the west, development has meant largely service delivery, especially health, education and transport, and questions concerning its funding from the abundant land and sea resources of the province.

The customary landowning groups to which almost every westerner belongs hold most of these resources. These groups themselves are organised, for the purposes of major resource development of their forests and reefs, under leadership of 'landowners', who are often entrepreneurially inclined. Western people have also been successful in past decades in developing a large, well-educated professional force of development-oriented government officials and business entrepreneurs, some of whom are landowners in their own right, while others are allied with landowners in a common spirit of development. Often, however, all the talk of development has seemed to go nowhere. Development plans gathered dust, parties argued and donor partner schemes came and went. This, and certain grievances against the national government, built up frustration with development. ${ }^{1}$

Calls for greater regional autonomy have come from the western Solomon Islands since the lead up to independence. Westerners have seen the centralised state as taking too much of their resources without delivering sufficient services in return. They have long wanted to develop the resources 
themselves and use the profits to provide services more directly. After a thwarted pre-independence proposal by the Western Council in 1975 that a federal structure be adopted for the coming nation - and a flurry of activity around a Western secession movement on the eve of national independence (Premdas et al. 1983; Dureau 1998) - the issue largely disappeared from the formal political agenda for many years, although it was aired during successive reviews of the provincial government system. ${ }^{2}$ From 1998, the Malaita-Guadalcanal conflict reignited the issues behind the autonomy movement. Concurrently, the national government concluded a long-running review of the provincial government system with a proposal to remove the provincial tier of government. In 2000, this combination of events propelled western political leaders to make a call (coinciding with the June coup d'état) for a federal system of government granting the west much greater autonomy.

Ethnicity played a greatly overt role in the 1998-2000 national conflict, including the way it played out in the west. Ultimately, however - as far as western interests were concerned - the conflict was based on the underlying economic relationship between the nation-state and the western people, particularly powerful landowners. The 1998-2000 conflict in the west began with ethnic violence, but was quickly channelled away from a specific conflict with Malaitans and propelled into a direct contestation with the national government over its failure to serve landowners' interests.

\section{Inequality between the provinces of Solomon Islands}

Solomon Islands has nine rural provinces plus Honiara, which is statutorily a town council separate from Guadalcanal. Production from primary resources is almost the nation's sole means for earning money from exports. During the mid 1990s, logging made up about half of exports and fishing about one-quarter in dollar terms. ${ }^{3}$ The resources contributing to this export revenue were distributed unevenly among the provinces in the pre-crisis period. Western Province provided 51 per cent of all log exports during 1995-96, Guadalcanal, Choiseul and Isabel contributed 10-12 per cent each, Malaita contributed just 6 per cent, and the others even less. As for fish exports, offshore joint-venture vessels took most of the catch, but among local players, Solomon Taiyo Limited in Western Province was the largest, 
taking 29 per cent of the 1998 catch. ${ }^{4}$ During the 1990s, Solomon Taiyo's Noro-based cannery and fishing fleet was also the largest employer in the country other than government (Bank of Hawai'i 1994; Aqorau 2001). By the late 1990s, prospectors had located viable gold and copper deposits in Western Province, particularly in Vangunu. To the extent that tax revenue was collected and used for public goods, the Solomon Islands government used western resources to subsidise poorer provinces although, as a later analysis showed, of all available recurrent public revenue, only about 30 per cent went to the provinces anyway, the other 70 per cent being consumed in Honiara by central government and the town council (Schindowski 2004).

While resources are concentrated in some provinces, population is concentrated in others. Western Province's rich resource endowment is coupled with moderate population, while elsewhere-particularly in Malaita - high population is mismatched with poor export resources. Malaita had 30 per cent of the nation's population in 1999, while Guadalcanal and Western provinces had 15 per cent each. All provinces in Solomons are feeling pressure on land-tenure systems due to high population growth. From 1970 to 1999 , the country's population grew 254 per cent (Solomon Islands Government 2002a, 2002b:8-11). Since the 1980s, land pressure has fuelled conflict throughout Solomon Islands - notably that created by the diaspora of Malaitans, with some ending up in 'New Mala' settlements located on old plantations and unoccupied customary land dotted around the country.

Apart from these land pressures, there have been underlying resentments, differing in each province, that the national government does not allocate treasury resources properly according to, variously, province of revenue origin or population size or cost of service delivery. Therefore, people in the west think they are being bled because their forest and fishery resources provide the majority of national revenue, but in their view they receive an inadequate return. The people of Malaita believe that they do not receive funds commensurate with their population size and people in Temotu (the most remote province) think they have been forgotten when it comes to services.

In the lead up to independence in 1978, Solomon Islanders representing rural interests challenged the presumption in Honiara that the central government should control the resources of the proposed new provinces. The old British Solomon Islands Protectorate's Western District — which 
was to become Western Province-instead proposed declaring its own national independence. In August 1977, a motion was moved in the legislative assembly that the central government 'amicably agree' to the west becoming a separate nation (News Drum 1977). The political situation in the west precipitated a crisis for the government, with a 'breakaway movement' developing, which led toWestern Province boycotting Solomon Islands' independence celebrations, although it eventually did stop short of declaring its own independence. Western grievances about the distribution of resources and the failure to accommodate western autonomy were then buried, but not forgotten.

\section{Sub-national identity in the west}

The 'west' in common parlance means the islands of the New Georgia Group and Shortlands, with Choiseul either included or named separately. Occasionally, the western end of Isabel (the Kia language area) is also alluded to as part of the western Solomons, but it falls into Isabel Province. The New Georgia Islands and Shortlands are the current members of Western Province, while Choiseul (formerly a part of Western Province) split off into its own province in March 1991.

It is useful to reflect on how, from indigenous viewpoints, the western region had become defined in political terms by 1978. Before colonial rule, the western Solomons - like any other part of island Melanesia — was a chain of small local polities not under any wider form of authority. The British clumped these together under districts, including the Gizo District in 1904 which later formed much of the Western Solomons District, and gradually introduced a geography of governance in terms of sub-districts, districts and the protectorate as a whole. ${ }^{5}$

In 1975, the western submission to the Kausimae Committee on Provincial Government phrased the experience of defining a sub-national identity in terms of historical destiny as follows

[t]ake the formation of the Western Council. The move of the different local government councils in the Western District to form the Western Council was initiated by local leaders with government encouragement. These leaders, through the increased awareness of their people in knowing that the Western District is in fact for them all and not for the Choiseul 
man or Marovo man only, came to realize that having one council would be better than having several. So the process of unity gradually grew. Many other factors contributed to the Western Council, but the process of unity and identity has spread from a tribe to a village, to a locality, to a whole island, to a district (Western Council 1975).

The main point here is that tribes and localities saw a common interest in amalgamating the five local councils in the west to form a more powerful identity-based political structure in 1972, the district council (Premdas et al. 1983:167). The effect of the British early on defining a 'Western District' was itself an important factor, because it was through this institution that the people of the west first experienced intimate colonial governance, back in the early 1920s. Coupled with this was the coterminous extent of the Methodist and Seventh-day Adventist missions, which in their early days operated exclusively in the west, adopting the western Solomons languages of Roviana and Marovo respectively as their lingua franca. Other parts of Solomon Islands were under different missions, adopting different local languages.

The third major factor in provincial identity is indigenous understanding of pre-protectorate history in terms of kin and custom. At that time, the islands of the western Solomons formed a maritime world of inter-island exchange, conflict and alliance, with little involvement with the east. Local populations in the New Georgia Islands by late frontier times comprised a mixture of people from all the islands of the west under the mantle of various local descent groups, each controlling their own area. This population mix included those intermarried from the New Georgia Islands themselves, as well as those abducted during raids or otherwise trafficked from Choiseul and western Isabel. ${ }^{6}$ Therefore, in any modern village in the west, many people can trace their ancestry at great-grandparent level to all parts of the western Solomons, especially Choiseul, New Georgia Islands and western Isabel. At this level, cases of descent from eastern Solomon Islands are very rare. Since colonisation and formation of the nation-state, the borders of the broad cultural area in which western people live have expanded eastwards and there has been more intermarriage between west and east. Even so, the presence now of very large numbers of people in western villages who trace one of their parents to Malaitan, Rennell-Bellonese, Guadalcanal or other eastern Solomons origin has little bearing on the sense of separate western identity. 
In a more complex sense, the west is also a reference to that which is a general feature of ethnic identity anywhere: a third-person group that acts as a counterpoint in the construction of identity. The nationally powerful Malaitans have figured large as this 'other' to the western sense of identity during most of the post-independence period. The combination of shared kin and customs, the regionally specific colonial district and mission territories and the perceived difference in identity from the eastern Solomons bequeaths a rich set of referents to 'westernness' that can be worked and reworked according to the political needs of the day.

\section{Colonialism and sub-national geopolitics}

Strategically, the crisis in the west hinged predominantly on relations with Bougainville and Malaita as other sub-national entities. Prior formation of attitudes to these entities is a critical factor, and these are now examined briefly in each case.

In early times, the Shortland Islands and southern Bougainville were together known as Sonto by people to their east, and by all accounts had much in common although this unity did not extend to Choiseul or the New Georgia Islands. ${ }^{7}$ The Germans and English drew their revised border through the old unity in 1899 (Moore 2003). Bennett (2000) has covered the colonial history of the relations between Bougainville and the western Solomons. Despite bans on cross-border movement, relations of marriage, land inheritance and customary trade were maintained between the people of southern Bougainville and the Shortland Islands throughout the colonial period. In the lead up to independence for Papua New Guinea and Solomon Islands, secessionists in Bougainville and leaders in Shortland Islands canvassed the possibility of Bougainville joining the Solomons (BSI News Sheet 1974; Hannett 1975). This did not eventuate, but it underlined the general sense of affinity.

Expressions of connectedness between Bougainville and the western Solomons resurfaced dramatically during the Bougainville armed conflict of 1989-98, when refugees and casualties flooded into Western Province and received shelter and medical treatment. ${ }^{8}$ The Bougainville militants were sustained partly by the supply links to Western Province markets, which in the early to mid 1990s brought invasion and attack on Solomon Islands 
civilians in Shortlands and Choiseul by the PNG Defence Force as part of its counter-insurgency operations. ${ }^{9}$ These events cemented many links of friendship and sympathy between Bougainvilleans and western Solomons people during the 1990s. Even so, whereas other groups from Solomon Islands can migrate permanently to the west, Bougainvilleans cannot. Perhaps because affinity was held at arm's length by the international border, Bougainvilleans are not thought of as imposing, but rather are thought of in positive terms.

In contrast with Bougainville, relations with Malaita are seen as imposed and are portrayed negatively. ${ }^{10}$ Of all Solomon Islands ethnic groups coming to the west, Malaitans have historically been the most contentious, with a long history of disharmony between Malaitans and locals. In colonial times, Malaitan plantation labourers came into the west as outsiders. The white plantation bosses thought Malaitans were more suitable labourers than the locals, and recruited them to live and work in labour enclaves separated from the indigenous westerners by space and cultural circumstances. Problems apparently arose early between the two groups in some regions: a district officer's report from 1913 details a fight between Roviana and Malaita youths on Rendova (Solomon Islands National Archives 1913; Bennett 1987:167-91). These enclave labourers remained working throughout the west until World War II, when the plantation days came to an end. Some remnants of Malaitan labour remained on the alienated land of plantations and, from the 1960s, more Malaitan labour came in for logging operations, but very little is known about the demography and history of such Malaitan immigration. By the 1990s, however, Malaitan settlements were dotted around the west, often on the so-called 'alienated land' areas. Title to these has been held by the Crown since colonial times, but often the land has been left dormant. Although all these areas are subject to indigenous claims stemming from various versions of pre-colonial ownership, development by people who regard themselves as the traditional landowners is frustrated by the Crown title. In the ensuing hiatus, Malaitan groups occupied some of these areas. It is resentment over these settlements that sparked conflict in the west in 1998.

Westerners often explain their resentment of Malaitans as being due to Malaitans' aggressive response if their customs are offended - and in some cases their ensuing demands for large sums of compensation money — which is not generally a western Solomons practice. Justly or not, many westerners 
also perceive thieving and sometimes sexual assault to be a trait of Malaitan settlers. While these are common themes when talking about Malaitans, it is also true that many Malaitans are married into western communities, thereby becoming in-law relatives. Malaitan-western children born to these marriages or through liaisons with western girls 'by the road' are integrated well into western communities and are usually not the target of such comments.

In the 1960s and 1970s, however, when marriages to Malaitans were novel, they led to much argument in villages. This was true on Kolombangara, where several local girls married Malaitan youths from Langalanga Lagoon in the 1960s. ${ }^{11}$ Some hold that those marriages were never right, but since that time, the families concerned have matured and become integral to the village and the issue has largely ceased to matter. Integration proved ephemeral as, in Kolombangara and presumably elsewhere in the west, the anti-mixing attitude resurfaced during the 1998-2000 crisis. In some cases, young women were gathered together while their elders exhorted them not to marry Malaitans. ${ }^{12}$ In terms of the geopolitics of the crisis, the stage was set by 1998 for the crisis to follow, with a benign, distant (and indebted) affinity to the west and an intertwined, resentful enmity to the east.

\section{The beginnings of ethnic tension in Western Province}

In the east, ethnic conflict between Guadalcanal and Malaita groups - fuelled by Malaitan migration to Guadalcanal_emerged in November 1998 with a spate of violence and a number of demands by Guadalcanal leaders to the national government. In the west, the demands of the Guadalcanal people were heard generally with sympathy. The ethnic conflict on Guadalcanal intensified again in June 1999, when fighting encroached on the outskirts of Honiara and road-blocks isolated the capital from the rural hinterlands. At that time, large numbers of Malaitans were displaced from Guadalcanal rural areas, either camping in town or moving to Malaita or other islands. Guadalcanal people similarly left town for the rural areas. In the panic that swept Honiara, people from other provinces also returned to those provinces. Dinnen (2002), Moore (2004) and Fraenkel (2004) chronicle these events in detail. The flow of people intoWestern Province in June 1999 was compounded by the usual influx for the mid-year school and college 
holidays. A common perception (by hearsay if not by observation) was that large numbers of Malaitans were among the influx and were joining relatives in settler camps all across the west. In the same month, ethnic violence also began in Western Province, with reports of houses being burnt along the Noro-Munda Road in New Georgia, in the area known locally as Ziata. Youths around Munda - who had old grievances with Malaitan youths from squatter settlements in the bush in Ziata - apparently began the burnings with the aim of driving the Malaitans away, in much the same way as had occurred on Guadalcanal.

The Noro-Munda area continued to be the main hot spot of ethnic tension in the west. In early March 2000, police intelligence identified two Bougainville men living in Munda, who were alleged to have been collaborating with local men in either restoring World War II guns or producing home-made guns that worked with recovered 1940s ammunition. A number of these guns were distributed locally and, it seems, were connected to Guadalcanal militant activity (Western Province Assembly 2000b). Following a trend beginning to emerge in Solomon Islands, late the next month, the Munda Police Station was raided by 'unknown elements' and eight small-calibre rifles were taken. ${ }^{13}$

\section{Western political response to the ethnic tension}

In June 1999, Clement Base, then Premier of Western Province, used a Solomon Islands Broadcasting Corporation (SIBC) radio interview to state the hard-line position of his province in relation to Malaitan people arriving there as a result of the recent inter-ethnic conflict in Honiara. In response, the western members of the national parliament met in Honiara with concerns that the interview could provoke an attack on Western Province people living in Honiara. Jackson Piasi, MP for Gizo/Kolombangara, made a media statement rebuffing Base's statement, and organised a national parliamentary representation to the premier (Solomon Islands Government 1999a).

The parliamentary committee consisted of Jackson Piasi, Nelson Boso (MP for Western New Georgia/Vonavona) and Job DudleyTausinga (MP for North New Georgia). They met with the premier and executive of theWestern Province government on 25 June 1999. The problem outlined by the premier at this meeting was increased agitation by western landowners over 'settlers' 
or 'squatters' from Malaita on or near their lands. The perception of many people in the west, he said, was that immigrants who were not rooted by marriage or work were responsible for much violence and theft, particularly around townships. Members of the meeting reported trouble in specific parts of the province, particularly the Munda-Noro region (including Ziata) and Gizo, with trouble also reported from Kolombangara, Ranongga and Rendova. They also identified towns, Temporary Occupation Licence (TOL) areas and old European plantations on alienated lands as being among the main places Malaitan settlers were to be found. The trouble reported had often to do with alleged theft by Malaitans of private or tribal-resource property (such as reef resources or timber), and Malaitan demands for high monetary compensation when wronged (Solomon Islands Government 1999a).

\section{Munda accord, July 1999}

The meeting developed a set of resolutions known as the 'Munda Accord' (Solomon Islands Government 1999a), which more or less proposed further consultations and investigation into the problem by the province and the parliamentary committee. In addition, a set of conclusions to this document expressed guiding sentiments for future action. Among these were

- Western Province wants to restrict the movement of lius (unemployed youth) in their Province, especially people from outside their province

- Western Province wants to set down stringent measures against its own people who allow their land to be settled by outsiders

- direct allocation of land other than for the purposes of public interest must be stopped outright in Western Province (Solomon Islands Government 1999a).

In August 1999, the premiers of Malaita and Western provinces co-signed a communiqué on the ethnic tension (Malaita-Western Premiers' Excursion 1999). The premier of Western Province agreed to 'abide by the Munda Accord for a peaceful repatriation of undesirable settlers who have caused pain and suffering to his people'. The most salient of the five points agreed to by the premier of Malaita Province was a call to Malaitans 'not engaged in formal employment, nor in any productive activities and who are staying without proper legal arrangements to voluntarily return to Malaita Province 
and participate in the development of the Province'. Implementation of the Munda Accord resolutions was slow, but began when members for a new Western Province coordinating committee 'for spill-over effect' were chosen among the Western Province Assembly members at a provincial caucus meeting on 21-22 March 2000 (Western Province Assembly 2000a). As this was occurring, another potentially explosive situation was developing within the national government.

\section{The provincial government review and the western response}

While never completely forgotten, the issues of regionalism were not dealt with decisively by any government in the Solomon Islands in the first 21 years of post-independence politics. The national constitution - drafted before independence- deferred the details of regional governance to a later time, when they could be debated in parliament on the recommendations of a review committee. This became the Kausimae Committee on Provincial Government which released its report in June 1979, 11 months after independence (Solomon Islands Government 1979). The report was equivocal on the issue of regional autonomy, and preferred not to mention the word 'state'. A Provincial Government Act was introduced in 1981, which, importantly, followed Section 106 of the constitution that 'no taxation shall be imposed or altered except by or under an Act of Parliament', limiting the power of the provinces to raise revenue. The act also gave the provinces no powers to make laws affecting trade and commerce with countries neighbouring Solomon Islands. Western aspirations were stymied.

A period of contradictory proposals for reform of the provincial system then followed. These vacillated between a nationalist preference for many local councils under strong central government (no provinces) and a subnationalist preference for strong provinces or states with a smaller central government. Sir Peter Kenilorea initiated the Provincial Government Review Committee in 1986, which culminated in its report and a white paper arguing for abolition of the provinces, produced after the new Alebua government had already taken office in December 1986 (Solomon Islands Government 1987, 1988b; Solomon Nius 1988b). Alebua ignored the continuing provincial review in favour of another process, in which he made former prime minister Solomon Mamaloni chairman of a new Constitutional 
Review Committee (CRC) in 1987, to look at devolving legislative and revenue-raising power to the provinces (Solomon Islands Government 1988a). ${ }^{14}$ Also equivocal in its recommendations, the committee introduced the idea of reforming provincial governments into states with expanded powers. Although the review raised expectations across Solomon Islands that a federal system of government would be introduced, the government changed again in March 1988, one month after the committee delivered its report. Even though Mamaloni had chaired the CRC, his new government chose to defer action on the review's recommendations in favour of minor reforms (Solomon Nius 1989a, 1989b). Then in 1996, Mamaloni-by then heading his third government - revisited the issue of provincial powers in a review of governance in Solomon Islands, passing a new Provincial Government Bill in which the provinces and local area councils were to be scrapped and replaced with provincial councils and area assemblies. Powers to the proposed councils were not increased; indeed, Western and Guadalcanal provinces argued that the reforms effectively diminished powers and the proposed changes were a bid by Mamaloni's government to increase its own power. After a legal challenge by Guadalcanal Province and further appeal by the government, the changes did not proceed because the Mamaloni government was voted out of office and the bill was repealed. ${ }^{15}$ The failed bid to abolish the provinces served to sensitise provincial leaders of the late 1990s to apparent central government attempts at increasing its power to the provinces' detriment.

The new Ulufa'alu government elected in 1997 continued to work on provincial government reform as part of its commitment to overall structural reform of the national government and economy. It set up a Provincial Government Review Committee in May 1998, which began its work (after some delay) a year later. This proceeded as the ethnic conflict in Guadalcanal gained momentum, but was set haplessly in pre-conflict terms of reference. The national government completed a draft of the resulting Provincial Government Decentralisation Bill by late January 2000 (Solomon Star 2000b). The bill was due to go before parliament in April 2000 and was a topic of controversy as the government - amid rising ethnic tension — was keeping secret the contents of the bill, although rumours circulated that the legislation would indeed de-institutionalise the provinces.

Meanwhile, the Western provincial government elections were held in December 1999. In early January 2000, the new provincial assembly 
members elected their premier, Reuben Lilo (Solomon Star 2000a). Lilo was elected on a platform of reform echoing the concerns of the national Solomon Islands Alliance for Change (SIAC) government in Honiara. In his first assembly meeting in late March, Lilo told the members, 'The need is urgent to establish "good" governance and transparency, restoration of financial stability, improving the quality of Provincial staff... and more importantly the development of the private sector'. ${ }^{16}$

His speech clearly expressed tension over the old issue of resources distributed to the province by the national government: '[w]e have been handicapped by the limited areas devolved by the National Government in which to legislate and to collect much needed funds to finance our projects and programs. ${ }^{17}$

Lilo was the west's man, representing the dominant entrepreneurial interests in the provincial town and among landowners and ordinary villagers. He spoke the language of development that the west liked to hear, and his success depended on how well he could carry it through.

Eventually, in mid March 2000, the draft Decentralisation Bill was sent to the provincial premiers for comment and, coincidentally, Lilo was invited to speak about the provincial government review at a conference in Honiara, where MilnerTozaka — at that time chairman of the review committee — was also making the first public presentation of the results of the review. The new system, Tozaka said, would be a 'two-tier constituency based system', removing the current provincial assembly and executive structures. Constituency Governing Councils (CGCs) would be formed instead, each covering a ward area (there are currently 26 wards in Western Province). A provincial congress made up of the presidents of the CGCs - headed by an elected governor-would coordinate the CGCs within a province while not forming a separate tier of government. The governor would take the place of the current premier and would mediate between the CGCs and the national government (Tozaka 2000). ${ }^{18}$

Various advantages were touted in Tozaka's paper for the new system, including greater grassroots participation in formal politics through the CGCs-whose members were to include chiefs, women and youth representatives - greater public benefit through articulation of provinciallevel planning with nationally coordinated service delivery agencies and a more active role for MPs at the provincial level. 
Criticism of the proposed system was heavy during the conference session, initially on the grounds that the government kept the bill secret rather than going through a 'green paper' public response stage. Then, led particularly by western Solomon Islanders in the audience, critics said that the proposal would lead to central government control with weak subnational representation. The first critique from the audience came from Warren Paia - a successful Honiara businessman, influential civil servant and powerful Roviana landowner - followed by Tony Hughes, a former Central Bank governor now based in the west, who called the plan stupid. In his own response Lilo, while noting the national government's fault in not providing him with the document early enough for him to read it thoroughly, rebutted the proposed system as being the antithesis of regional autonomy, which he stressed was the wish of people in the west.

Lilo returned to the west concerned about the contents of the proposed bill. In response to the news the provincial assembly, which met a few days later, passed a motion calling forWestern Province to attain statehood under a federal government system by 2005. The main rationale given for the motion by the member tabling it, Thornley Hite, was that the annual grant from the national government, on which the province based most of its budget, was insufficient to maintain provincial services. At the same time, the province had few powers to raise revenue itself. He raised the old theme that relative to other provinces, westerners 'produce more but receive less'. The discussion before passing this motion expressed sentiments that this was a long-awaited motion. The premier noted that, according to his reading of the Provincial Government Review Committee report, a number of submissions from other provinces had called for a federal system. ${ }^{19}$ An interesting reflection by one member was that the issue of autonomy had been hard to raise since the separation of Choiseul from Western Province. As it was, the motion before the assembly included a clause for a new 'federal statehood' working committee to look into the re-amalgamation of Choiseul and Western provinces as one state.

\section{Western leaders' communiqué, April 2000}

Coming out of the assembly meeting, Lilo set a joint meeting for the provincial and national political representatives to form a Western Province response to the issue (Western Province Assembly 2000a). The Western 
Leaders' Consultative Meeting occurred in Gizo in early April, two weeks after the Honiara conference. It was attended by western politicians in national and provincial seats, provincial business professionals, town business leaders and a number of landowners from nearby islands (Western Leaders' Consultative Meeting 2000a). ${ }^{20}$

The Western Leaders' Consultative Meeting (2000b), which began the following week, developed a set of resolutions for delivery to the national government. The preamble noted that 'the way forward economically and politically lies in greater political and economic autonomy of the Province' and 'real and sustainable development can only occur in an environment of peace and security as well as in the ownership and control of all natural resources in the Province'. Following on from this, the crux of the resolutions were that

- a substantial portion of the revenue generated in the Western Province be retained in the Province and relevant legislation be amended accordingly.

- security issues should be addressed immediately in line with the Munda Accord.

- the National Government with immediate effect prepare the Province for the attainment of State Government by 2005, and that it should reconsider the implementation of the proposed Provincial Government Bill.

- the National Government immediately transfer all alienated land and other government assets to the government and people of Western Province (Western Leaders' Consultative Meeting 2000b).

The resolution also included a number of demands relating to economic development in the province, including building an international airport at Munda and implementing other provincial development projects previously agreed to, but never enacted, by the national government.

A second Western Leaders' Consultative Meeting occurred in late May. The call for a federal state government system was reiterated. In order to develop a constitution for the new state entity and to report the desired changes to the national constitution, this meeting established a task force for statehood that was to report by September 2000. Comments at the meeting made clear that security was deteriorating in Solomon Islands, with the police virtually incapable of operating independently. Another 
result of the meeting was initiation of aWestern Province Security Council, membership of which included the police commander, Aloysius Ora; the premier; Jackson Piasi, MP for Gizo/Kolombangara; and Albert Laore, MP for Shortlands. They were to set up a plan that included recruiting a Western Province constabulary and put in place a 'security consultative arrangement' (Western Leaders' Consultative Meeting 2000c).

\section{Sub-national geopolitics and the 5 June 2000 take-over}

On the same weekend as the leaders' meeting, a notice signed by 'Black Shark' appeared around Gizo telling Malaitans they had three weeks to get out ofWestern Province. ${ }^{21}$ There was considerable speculation as to who posted it. One theory was that a Malaitan, John Fo' ogau — pictured a few days later on the front page of the Solomon Star in a Malaita Eagle Force (MEF) unit, holding an automatic weapon - posted the notice in order to destabilise the situation. Another theory had it posted by the Black Shark armed combatant group from southern Bougainville, who allegedly shot dead one of Fo' ogau's men soon after. This group was referred to also as 'Spear'.${ }^{22}$ Later allegations suggested Black Shark posted the notice in an effort to create a situation in which the province would contract the group to provide security. ${ }^{23}$ The conflicting rumours flying around Gizo as to which outside force was to blame indicated how quickly things were becoming confused. The notice had a dramatic effect. Police were dispatched to various centres in the west, including Ringgi on Kolombangara, requesting people not to spread unsubstantiated rumours or exaggerated stories about anti-Malaitan activities. Their fear was that the MEF or other Malaitans in Honiara would hear those stories and retaliate against western people in the capital. ${ }^{24}$

Some days after the second leaders' meeting, the police armoury at Rove was overrun and Andrew Nori announced that the MEF and the joint operations force had 'declared war' against Guadalcanal's Isatabu Freedom Movement (IFM) (Nori 2000). This was the 5 June coup. By this time, various Bougainvillean combatant leaders had arrived in Western Province for negotiations. Ishmael Toroama, a Bougainville Revolutionary Army (BRA) commander from Central Bougainville, was in the area to provide security to one of the SIAC government MPs who had returned home from Honiara after receiving threats. Others, said to be from a southern Bougainville 
BRA faction led by Cornelius Solomon, were in the Munda area. ${ }^{25}$ The combatants from Bougainville were battle hardened, fully armed guerrilla soldiers who had been active fighters in the Bougainville insurgency against PNG Defence Force troops.

In the early morning of Sunday 11 June, a contingent of about 37 wellarmed Bougainville men, accompanied by some western Solomon Islanders, arrived in Gizo by canoe. Most of these combatants were from southern Bougainville. They announced publicly their intention to protect Western Province in the case of any insurgency by Malaitans or attempt by the MEF to take over the provincial town. On the same day, Bougainville militants raided the police armoury in the Choiseul provincial town on Taro Island. ${ }^{26}$ Their arrival in Gizo had at least the tacit support of the Western Province government and the police in Gizo. While not stated as such, this appeared to be part of the 'security consultative arrangement' mentioned in the western leaders' meeting of late May. ${ }^{27}$

A few days of mayhem followed. There was a general fear that the MEF would sweep in, take control of Gizo and thence the west. Some of the Bougainvillean combatants, who materialised suddenly, visited a house in Gizo looking for MEF sympathisers and their weapons, and shot a youth who was said to have produced a pistol (see, for example, SIBC 2000a). Simultaneously, some youths in Dunde, Roviana, ran amok, brandished 'home guns' (home-made light firearms), took outboard motors and demanded that people hand over their kurukuru (pigeon-shooting) guns. Bougainvillean combatants suppressed this group. ${ }^{28}$ Meanwhile, the general secretary of the BRA, Robinson Asotau, issued a press statement that denied BRA involvement in the Gizo shooting, but said that a man from Buin (south Bougainville) was involved (SIBC 2000a). The president of the Bougainville People's Congress, Joseph Kabui, also denied BRA involvement in the Gizo events (Solomon Star 2000d). In any case, a large army of Bougainvillean counter-insurgents dressed in 'Rambo'-style, motley combat fatigues had occupied Gizo. More armed combatants in 21-foot Yamaha boats-a hallmark of the BRA — were patrolling the waters around the islands every night. 'Mae karangge nius' (rumours) of an imminent MEF insurgency abounded in the townships and villages of the west.

Malaitans continued to leave the west in the face of threats to their safety. About 50 left the alienated land area of Kolombangara, while many 
left from the Koqulavata and FishingVillage areas in Gizo. Two months later, the Malaitan premier, David Oeta, claimed 500 Malaitans had fled the west (SIBC 2000i). It is difficult to determine the accuracy of that figure, but my impression is that most who fled did so during June. The outflow of Malaitans was matched by an inflow of westerners and their luggage from Honiara to Gizo and elsewhere in the province. Gizo began filling with taxis relocated from Honiara. Although people had been moving to the west for months as a result of the general unrest - a phenomenon seen first in June 1999-a new incentive for relocating was fear of reprisal attacks by Malaitans on western people in Honiara, for these had begun. A Malaitan church leader exacerbated tensions by declaring publicly later in June that Malaitans were being harassed to move. The premier desperately denied in the media 'that Malaitans leaving Western Province have been displaced due to threats from people of Western Province' (Solomon Star 2000f; SIBC 2000c). In Gizo town itself, an uneasy calm settled under the Bougainvillean 'assistance mission'. Talk turned to the question of 'what next'?

Gaining the upper hand: the western state declaration under arms The take-over of the central government apparatus in Honiara by Malaitan forces projected the ethnic dimension of the conflict holus-bolus into an issue of who should control the nation-state. The powerful underlying Malaitan 'labour' agendas stemming from their own long history of contest with the central government, notably including the Ma'asina Rule Movement of the 1940s (Laracy 1983; see also Moore 2007), confronted the western 'natural resources' agendas. On Monday 26 June, executives of Choiseul and Western provinces sat in a joint meeting and decided to declare on national Independence Day (7 July) their intention to form a joint, federalstyle state government (Solomon Star 2000e; SIBC 2000b). This was the cementing of the Western and Choiseul province forces mooted back in the March provincial assembly meeting as necessary to invigorate fully the long-quiescent federal statehood agenda, which had been discussed in private ever since the MEF take-over of Honiara earlier that month.

It was well understood that to become a state within a continuing nation, there would still need to be a process of constitutional and legislative change by the national parliament. Nevertheless, for many, the nuance of 
an 'intention' to declare a state within a federation was too fine, and even the title of Lilo's public speech on national Independence Day was 'on the occasion of declaration of State Government in the region' (Lilo 2000a). The decision to advance the pace of the movement by the declaration reflected the growing currency of more radical views among the political community in and around Gizo. Despite his declaration, Lilo's opposition described him as too moderate. There was a mood of 'to hell with the national government' which, after the announcement in early July of Manasseh Sogavare (from Choiseul) as new prime minister and his new cabinet, many thought of as no more than a puppet regime of the MEF. ${ }^{29}$ This was because the Ulufa' alu government had been deposed and the new government had come into office without election. With BRA militants in the background, Lilo expressed in his Independence Day speech the 'inalienable right' ofWestern and Choiseul provincial peoples to 'remove any threat' that 'interfered with' the ideals of peace and freedom, and to 'confirm... our very existence as a people, and our resources and other indigenous rights, as opposed to our constitutional rights and obligations'. Lilo stopped just short of an unambiguous unilateral declaration of statehood within a federation, saying instead

That from this day on, we the people of Western Solomons do hereby renew our commitment to achieving State Government...

We raise our flag today in recognition of our sincere and noble desire to have

- Autonomy

- Indigenised democracy

- Rule of law

- Legislative powers over our own resources and in the conduct of governance in the State of Western Solomons (Lilo 2000a).

Calls of 'God bless the state of Western Solomons' and 'God bless the sovereignty of Solomon Islands' followed and, despite the careful wording, a new State of Western Solomons flag was raised (Solomon Star 2000h). After this, 'State of Western Solomons' letterhead was used on official correspondence. The flag and the letterhead were further triumphs for those who wanted quick action on the issue.

Lawlessness in the west appeared to be rising during July. All banks in Gizo had closed due to an armed robbery, then a Solomon Taiyo fishing 
vessel was hijacked and a rest-house at Noro was held up (Solomon Star 2000i, 2000j; SIBC 2000f, 2000h). This in turn justified for many people the premier's position in his 7 July speech (and earlier) that the west should take care of its own security measures. Honiara, however, criticised this policy as illegal. Matters did not rest there. In response to the drying up of national funds to the provinces, Lilo then signed a memorandum on 2 August instructing the Gizo sub-treasurer of the Ministry of Finance to redirect all payments made by the public straight to the 'state treasurer'. These funds, he said, would be taken by the state government and used according to the provincial budget allocations already published in the national government's Approved Recurrent Estimates for 2000 and the other budget papers approved by the parliament (Lilo 2000b).

The national government showed consternation at this early declaration of western statehood. The Minister for Provincial Government, Nathaniel Waena, made a public statement later in the month that all provinces were still operating under the national constitution and the Provincial Government Act and that none had become a state (SIBC 2000g). Nonetheless, Waena and Sogavare took the statehood issue seriously, unlike Ulufa' alu before his house arrest. On Independence Day, Sogavare had mooted publicly the possibility of a shift to a state government system (SIBC 2000e). Waena organised the Solomon Islands government 'peace delegation' to Western Province to hold discussions in various places in the west, and visited Shortlands, Choiseul, Gizo, Noro, Munda and Marovo during mid August (SIBC 2000j). ${ }^{30}$ Waena pronounced during the delegation's Gizo public meeting that 'the nation has got to a point of no return. The question is how to prepare the nation for a federal system of government or state government.' He and his official mentioned that a premiers' conference was planned for mid October to 'divide powers' ${ }^{31}$ By August, pressure had begun from most other provinces for a greater degree of decentralisation. Temotu began to negotiate separate trade and shipping arrangements with neighbouring Vanuatu, based on Temotu having not been part of the 1893 British protectorate; Makira-Ulawa wanted to become an independent nation; Isabel remembered that it had been German territory until the late 1890s; and Polynesian outliers RennellBellona began preparing a constitution to become a state within a federal system. Even small Central Islands Province demanded more autonomous relations with the national government (Moore 2004:156-60). 
During the whole period since the May leaders' meeting, four western state task forces - political and legislative, economics and commerce, human resources development and security — had been busy. Taking up a large, well-resourced office in Gizo, and engaging in many evening discussions in rooms of the Gizo Hotel, the most active members even created a multiissue newsletter, The Prunsvick, between September and October, the title a reference to the Prunsvick Association of the 1978 Western Breakaway Movement (Premdas et al. 1983:54). A key reference document for the political and legislative task force was the 1987 Constitutional Review Committee Report, with its federalism recommendations. In mid October, the western state task forces presented their findings to the last of the Joint Leaders' Meetings, two days after the Townsville Peace Agreement (TPA) was signed by the MEF and IFM leaders, the prime minister and the provincial premiers, including Lilo. The great topic of the leaders' meeting, which was full to overflowing with members of the public, was the new western state's development plans. With the audience in high excitement, speakers bandied wild talk of millions in newly allocated foreign funds. The TPA had, however, included an agreement to halt unconstitutional action on state government pending a full constitutional review of a new prospective federal system. News of this filtered back, taking heat out of the movement just as expectations appeared to go beyond reasonable bounds. The threat of MEF incursion, which was looking unlikely by this stage, was also contained.

\section{The national government's response to the crisis}

Under the TPA of mid October 2000, the Solomon Islands government was mandated to introduce a form of government that would give more autonomy to the provinces. As a first step, the government organised a week-long premiers' conference in Buala in mid November (Premiers' Millennium Conference Buala 2000a). Several reports were prepared for this conference, dealing with the legal and administrative requirements for the proposed changes, levels of provincial funding and a report on the provincial governments' own submissions (Saunana and Faluaburu 2000; Solomon Islands Government 2000; Teutao and Tuhaika 2000; Sore et al. 2000). It was noted that almost all provinces had commented on the need to devolve more legislative powers and functions, and provide extended powers of 
taxation and revenue raising and freedom to source their own funds. Among the most important of the background papers were the comprehensive western state government task force reports. At the conference's end, the premiers resolved that the national government adopt a 'Homegrown State System of Government for Solomon Islands whereby each respective province should become a State with its own State Constitution', and that the national constitution should be amended accordingly (Premiers' Millennium Conference Buala 2000b).

In response, Sogavare's national Peace, Reconciliation and Unity government set up a task force to revisit the constitutional review of 1987. In working through these issues, the task force developed a draft Constitution Amendment (Creation of the Federation) Bill in July 2001, along with budget estimates for the state government system (Solomon Islands Government 2001a, 2001b). The main proposals were presented a couple of months earlier in the Report of the State Government Taskforce. These proposals were largely an amalgam of recommendations from the 1987 Constitutional Review Committee Report and the 1999 Report of the Provincial Government Review Committee. Many of the Western Province demands were met. These, all of them important, gave many concessions to the powerful landowner-entrepreneur factions that had been at the forefront of western demands. Among the proposals were the following key reforms

- establishment of a federal republic of Solomon Islands

- state constitutions to be formed with strong legislative powers

- customary landowners to receive rights to all minerals in their land and to have unregulated rights over their land and resources

- alienated lands to be returned to traditional landowners unless excised for specific purposes (such as land for state headquarters)

- financial power to be devolved, including a provision that taxes can be raised and kept by the states

- states to share primary produce export levies with the federal government, and a finance council consisting of state premiers and national cabinet ministers to share other federal funds with the states.

The west gained all its key demands for control of its resources and revenue. In this way the bulk of recommendations suited the resource-rich provinces, 
notably Western and Choiseul. For the resource-poor but labour-strong Malaita, the recommendations did not support the inter-provincial labour migration on which many Malaitans depend.

Subsequently, consultations facilitated by the United Nations Development Programme (UNDP) were held throughout the nation and a draft federal constitution was prepared. The government of Sir Allan Kemakeza made slow progress and lost office before introducing the bill in 2006 as promised. ${ }^{32}$ The draft was, however, discussed in parliament in December 2005, resulting in the instruction for the drafting process to continue. The incoming Grand Coalition for Change government under Sogavare proceeded cautiously by commissioning an audit of the draft constitution, but indicated in its policy framework of May (2006; see also Solomon Star 2006) that it regarded the reforms as a 'pressing issue' and it would 'pursue the adoption of a federal constitution forthwith' as part of its 'bottom-up approach'.

The draft federal constitution in its current form mirrors substantially the 2001 bill for the creation of a federation, in which the demands of western landowners and their entrepreneurial allies were largely met. At this point, it appears that the decades-old western struggle against Solomon Islands' central state has come into the field from behind and won hands down against the players fighting the bloody and ultimately pointless Guadalcanal conflict in the main arena of the 1998-2000 conflict. There are valid questions as to whether the entrepreneurial landowner interests that favour state government of the federal type proposed are the same interests as those of rural smallholders or those of resource-poor provinces. It has become a matter of faith, however, among Solomon Islanders that federalism of the type formulated by the western state task force during 2000 is the only alternative to the current form of national government. The few challenges and alternatives to this model have been left unheeded or disparaged by Solomon Islanders, who see in any of these only an attempt to subvert hard-won gains and reinforce the status quo of strong central government with weak sub-national government (Scales 2005). The belief in a state government system has, if anything, grown stronger in reaction to the views of foreign advisors, who appear to be concerned that the policy is flawed from administrative and economic points of view. ${ }^{33}$ 


\section{Conclusion}

The west's brief flirtation with ethnic ideologies in 1998-99 was quickly overtaken by revitalisation of the western state movement, with its central goal of reclaiming control of western resources. By advocating sub-national autonomy against the backdrop of a mismanaged central state, the proposals of Western Province politicians in early 2000 struck an emotional chord across Solomon Islands to do with land, development aspirations and identity. These were, however, essentially the calculated, self-interested actions of a small élite group with a self-appointed task to reshape national governance. Perhaps the outcome would have been different if Malaitan politicians had presented their own detailed proposal for state reform, which articulated their best interests with respect to the all-important national geographic balance between natural resource distribution and population, or if any other province had similarly done so. In the event, we can ask if the real coup in Solomon Islands was that by the MEF on 6 June 2000 or if it was that of Western Province landowners, marked by the raising of the State of Western Solomons flag on 7 July 2000.

\section{Acknowledgments}

The author would like to thank the Crawford School of Economics and Government at The Australian National University, Canberra, for support during the writing of this paper.

\section{Notes}

1 For details of development issues in Western Province, see Foale 2001; Hviding 1996; Hviding and Bayliss-Smith 2000; McDougall 2005; as well as Scales 2004.

2 From time to time, breakaway ideas were also mentioned in the national Independence Day speeches in Gizo (see Tausinga 1987).

3 Central Bank of Solomon Islands (2001) and Foreign Exchange Department figures. For example, in 1996, the composition of exports in Solomon Islands dollars was: logs, 56 per cent; fish, 24 per cent; palm oil and kernels, 10 per cent; copra, 4 per cent; cocoa, 3 per cent; and all other exports, 3 per cent.

4 Data in Hand (1999:70-5) gives the share of the total fish catch in 1998 (in metric tonnes) as: Solomon Taiyo Ltd, based in Noro, 35,812; NFD, based in Tulagi, 19, 546; various foreign-based joint ventures, 68,376; others, 1,775-making a total of 
125,509. Gillett and Lightfoot (2002: Appendix 2, 193ff.), however, give an extended commentary as to difficulties with fisheries data for Solomon Islands in the 1990s.

5 TheWestern Solomons District was a post-war (April 1944) amalgamation of the Gizo, Shortland andYsabel Administrative Districts. See District of Western Solomons 1951; also Bennett 1987:398.

6 On slaves sourced from western Isabel, see Jackson 1975.

7 For details, see Scales 2004; also Oliver 1955:17, 295. For mention of Sonto and its location, see Thurnwald (1909:527) and Hocart (1922:95) — the latter of whom says that 'Sonto appears to lie in Bougainville'.

8 The Solomon Islands Red Cross had care centres for Bougainville refugees in Gizo, Taro Island and Guadalcanal, while the Solomon Islands government provided asylum and free health care (see Red Cross 1999).

9 This included the killing of two Solomon Islands civilians in Kariki village about September 1992 (May 1993; Kabutaulaka 1998:40). Also see Office of the Prime Minister 1996; Spriggs 1992.

10 This imposition and negative sentiment is the crux of the argument in Dureau 1998.

11 Silas Bio, Ghatere Village, Kolombangara, personal communication, 1999.

12 I heard at the time that this had occurred in Hunda and Kena villages on Kolombangara in $\operatorname{mid} 2000$.

13 The raid occurred on 26 April (Solomon Star 2000c).

14 For commentary, see Larmour's (1989) review of the report and his later summary that the CRC was 'conservative, authoritarian and ethnically defensive' - in Larmour (1990). See also Ghai 1990. Solomon Nius (1988a) reported the presentation of the report to the prime minister.

15 The Provincial Government Bill 1996 (Pacific Manuscripts Bureau 1292) repealed the Provincial Government Act 1981 — and itself was soon repealed by the Provincial Government Act 1997. For expanded treatment of the various reviews until about 1990, see Frazer 1995. For the early 1980s, see the treatment by Larmour (1985). For later developments, see Nanau 2002.

16 'Premier's address to the full assembly-March/April 2000' (Western Province Assembly 2000b).

17 Ibid.

18 I attended this conference. The full report (Solomon Islands Government 1999b) was soon after distributed to the provinces.

19 'Western Provincial Assembly: budget session [2000-01]' (Western Province Assembly 2000b).

20 I attended this and some subsequent leaders' meetings.

21 I did not see a copy of this notice and do not know what the exact wording was. Apparently, it was posted on the night of Sunday 28 May. Other reports say the notice was also posted in Munda and Noro (Fraenkel 2004:88).

22 A corruption of SBIA - the South Bougainville Interim Administration - an organisation that ceased to exist by late 1992 as a result of internal southern Bougainville power 
struggles. These had occurred when hard-line pro-Bougainville Revolutionary Army (BRA) elements close to Francis Ona gained ascendancy and a number of SBIA moderates were killed - upon which other moderates joined the PNG Defence Forcealigned Bougainville Resistance Force (BRF). The term 'Spear' (SBIA) perhaps gained currency in western Solomons to describe continual border crossing into Solomon Islands by southern Bougainvilleans involved in fighting in the associated complex, difficult to understand, internal battles in Buin and Siwai during 1991-92. The term Spear continued to circulate in western Solomons well after SBIA disappeared-perhaps in distinction to the 'legitimate' BRA involved in negotiations in Honiara, which had formal links with the Solomon Islands government and whose members were mostly from Central Bougainville (Tony Regan, personal communication, 2007).

23 In a later commentary, Andrew Nori, a leader of the MEF coup in Honiara, claimed Black Shark had formed with the encouragement of the Western provincial government, 'together with some prominent businessmen in Gizo and in the Noro/Munda area', and was joined later by 'criminals and mercenaries from South Bougainville...to provide security for the people of Western Province from any imminent attacks by the MEF' (SIBC 2001). While Black Shark eventually became a code name for the armed groups in Gizo and Munda, it evidently began before the 5 June coup and might or might not have had early backing from the provincial government or other political leaders in the province.

24 Two police officers visited Ringgi on the weekend of 3-4 June with this message.

25 I heard this information at the time. Solomon was a member of BRA from Buin, who in 1997 was listed in BRA documentation (dated 26 December 1997) as the Company Commander, BRA Southern Marine (Tony Regan, personal communication, 2007).

26 This information is partly from rumours I heard while staying on Kolombangara at the time. Fraenkel (2004:88) and Moore (2004:13-14) provide further details based on news reports.

27 Two unrelated people I have spoken to say they have held a copy of the security arrangement document, which they both say was between the Western Province government and BRA militants from Bougainville.

28 Email from (name suppressed), 25 June 2000.

29 Sogavare was declared prime minister on 30 June (SIBC 2000d). Ministers in the new Sogavare government swore their oaths in early July 2000 (Solomon Star 2000g).

30 Waena was Minister for Provincial Government in Mamaloni's second government (March 1989-June 1993)_-ironically, responsible for deferring action on the then widely expected federal system proposed in 1988 .

31 Meeting notes, 10 August 2000, Gizo. This eventually became the Buala Premiers' Conference.

32 National community consultations were held between January and March 2003. See Solomon Islands Government 2003, 2004; Solomon Star 2005.

33 The most systematic critique is that of the audit commissioned by the Solomon Islands government in August 2006 (Institute of Policy Studies 2007). 


\section{References}

Aqorau, T., 2001. 'Sustainable management and development of Solomon Islands fisheries resources', Pacific Economic Bulletin, 16(2):120-6.

Bank of Hawai'i, 1994. An Economic Assessment of Solomon Islands, July.

Bennett, J.A., 1987. Wealth of the Solomons: a history of a Pacific archipelago, 1800-1978, University of Hawai'i Press, Honolulu.

- 2000. 'Across the Bougainville Strait: commercial interests and colonial rivalry, c. 1880-1930', Journal of Pacific History, 35:67-82.

BSI News Sheet, 1974. BSI News Sheet, (22), 6 December.

Central Bank of Solomon Islands, 2001. Annual Report 2000, Central Bank of Solomon Islands, Honiara.

Dinnen, S., 2002. 'Winners and losers: politics and disorder in the Solomon Islands, 2000-2002', Journal of Pacific History, 37(3):285-98.

District of Western Solomons, 1951. District of Western Solomons Annual Report 1951, BSIP 7/I/DCW 140A, Solomon Islands National Archives, Honiara.

Dureau, C., 1998. 'Decreed affinities: nationhood and the Western Solomons', Journal of Pacific History, 33:197-220.

Foale, S., 2001. 'Where's our development', Asia Pacific Journal of Anthropology, 2(2):44-67.

Fraenkel, J., 2004. The Manipulation of Custom:from uprising to intervention in the Solomon Islands, Victoria University Press, Wellington.

Frazer, I., 1995. 'Decentralisation and the postcolonial state in Solomon Islands', in B.V. Lal and H. Nelson (eds), Lines Across the Sea: colonial inheritance in the post-colonial Pacific, Pacific History Association, Brisbane:95-110.

Ghai, Y., 1990. 'Constitutional reviews in Papua New Guinea and Solomon Islands', The Contemporary Pacific, 2(2):313-33.

Gillett, R. and Lightfoot, C., 2002. The Contribution of Fisheries to the Economies of Pacific Island Countries, Asian Development Bank, Manila.

Grand Coalition for Change Government, 2006. Policy Framework Document, May, Honiara.

Hand,T., 1999. A Review of Fisheries Taxation and Licensing in the Solomon Islands, Asian Development Bank, Manila.

Hannett, L., 1975. 'The case for Bougainville secession', Meanjin Quarterly, 34(3):286-93. 
Heath, I.C., 1974. Charles Morris Woodford of the Solomon Islands: a biographical note, 1852-1927, M.Qual. thesis, The Australian National University, Canberra.

Hocart, A.M., 1922. 'The cult of the dead in Eddystone of the Solomons', Journal of the Royal Anthropological Institute of Great Britain and Ireland, 52.

Hviding, E. and Bayliss-Smith, T., 2000. Islands of Rainforest: agroforestry, logging and eco-tourism in Solomon Islands, Aldershot, Ashgate.

Hviding, E., 1996. Guardians of Marovo Lagoon: practice, place and politics in maritime Melanesia, University of Hawai'i Press, Honolulu.

Institute of Policy Studies, 2007. Report of the constitutional audit of the draft Federal Constitution of Solomon Islands, Institute of Policy Studies, School of Government, Victoria University, Wellington.

Jackson, K.B., 1975. 'Head-hunting in the Christianization of Bugotu 1861-1900', Journal of Pacific History, 10:65-78.

Kabutaulaka, T.T., 1998. Pacific islands stakeholder participation in development: Solomon Islands, Pacific Islands Discussion Paper Series, World Bank, Washington, DC.

Laracy, H.M., 1983. Pacific Protest: the Maasina Rule Movement, Solomon Islands, 1944-1952, Institute of Pacific Studies, University of the South Pacific, Suva.

Larmour, P., 1985. 'Solomon Islands', in P. Larmour and R. Qalo (eds), Decentralisation in the South Pacific, Institute of Pacific Studies, University of the South Pacific, Suva.

_ 1989. 'Book review of 1987 Constitution Review Committee Report', The Contemporary Pacific, 1(1-2):203-5.

- 1990. 'Ethnicity and decentralisation in Melanesia: a review of the 1980s', Pacific Viewpoint, 31(2):10-27.

Lilo, R., 2000a. Speech delivered by the Premier ofWestern Province, Hon. Reuben Lilo, on the occasion of the declaration of State Government in the region on 7 July, TS.

— , 2000b. Memorandum to Sub-Treasurer Gizo, from Hon. R. Lilo, Premier Western State, 2 August.

Malaita-Western Premiers' Excursion, 1999. Communiqué: the Western Province ethnic tension: Malaita-Western premiers excursion, Threepage document, signed 18 August 1999 by Hon. David Oeta, Premier for Malaita Province, and Hon. Clement Base, Premier for Western Province (Pacific Manuscripts Bureau, 1292). 
May, R.J., 1993. The changing role of the military in Papua New Guinea, Papers on Strategy and Defence, No.101, Strategic and Defence Studies Centre, Research School of Pacific and Asian Studies, The Australian National University, Canberra.

McDougall, D., 2005. 'The unintended consequences of clarification: development, disputing, and the dynamics of community in Ranongga, Solomon Islands', Ethnohistory, 52(1):81-109.

Moore, C., 2003. New Guinea: crossing boundaries and history, University of Hawai' i Press, Honolulu.

— 2004. Happy Isles in Crisis: the historical causes for a failing state in Solomon Islands, 1998-2004, Asia Pacific Press, The Australian National University, Canberra.

_ 2007. 'The misappropriation of Malaitan labour: historical origins of the recent Solomon Islands crisis', Journal of Pacific History, 42(2):21132.

Nanau, G., 2002. 'Uniting the fragments: Solomon Islands constitutional reforms', Development Bulletin, 60:17-20.

News Drum, 1977. News Drum, 28 August.

Nori, A., 2000. Transcript of radio broadcast by Andrew Nori, SIBC News, 7 June.

Office of the Prime Minister, 1996. Reports on Border Incursions 1996, 6 December, Office of the Prime Minister, Honiara.

Oliver, D., 1955. A Solomon Island Society: kinship and leadership among the Siuai of Bougainville, Harvard University Press, Cambridge, MA.

Premdas, R., Steeves, J. and Larmour, P., 1983. 'The Western Breakaway Movement', in P. Larmour and S. Tarua (eds), Solomon Islands Politics, Institute of Pacific Studies, University of the South Pacific, Suva:16495.

Premiers' Millennium Conference Buala, 2000a. Premiers Millennium Conference Buala, Isabel Province: Day 1: Monday 13 November 2000 Proceedings, \&., Five volumes (Pacific Manuscripts Bureau, 1292).

- 2000b. Communiqué, 17 November.

Red Cross, 1999. International Federation of Red Cross and Red Crescent Societies. Available from www.ifrc.org/docs/appeals/annual99/013499. pdf.

Saunana, J. and Faluaburu, S., 2000. A report on provincial governments' submissions on the proposed federal system for Solomon Islands, October, Bound reports from the Ministry of Provincial Government and Rural Development, Honiara (Pacific Manuscripts Bureau, 1292). 
Scales, I., 2004. The social forest: landowners, development conflict and the state in Solomon Islands, $\mathrm{PhD}$ thesis, The Australian National University, Canberra.

— 2005. 'State and local governance in Solomon Islands: building on existing strengths', Pacific Economic Bulletin, 20:140-7.

Schindowski, D., 2004. The implications of the constitutional reform from an economic point of view, TS dated July 2004 for United Nations Development Programme consultancy. Available from www.vanuatu. usp.ac.fj/library/Paclaw/SolomonIslands/SIConstitutionDraftIMP.pdf (accessed September 2005).

Solomon Islands Broadcasting Corporation (SIBC), 2000a. SIBC News, 12 June.

, 2000b. SIBC News, 26 June.

- 2000c. SIBC News, 28 June.

- , 2000d. SIBC News, 30 June.

$\longrightarrow$, 2000e. SIBC News, 6 July.

— 2000f. SIBC News, 14 July.

— 2000g. SIBC News, 25 July.

- 2000h. SIBC News, 27 July.

, 2000i. SIBC News, 9 August.

- 2000j. SIBC News, 14 August.

— 2001. '5th June 2000 in perspective', SIBC, December. Available from www.sibconline.com.sb/Analysis\%20archive.asp

Solomon Islands Government, 1979. Report of Special Committee on Provincial Government, December 1977-May 1979, Solomon Islands National Parliamentary Paper 14/79 (Pacific Manuscripts Bureau, 1190).

_-1987. Report of the Provincial Government Review Committee 1986-1987, Ministry of Home Affairs and Provincial Government, Honiara.

—_, 1988a. 1987 Constitutional Review Committee Report, Three volumes, Solomon Mamaloni (chair), Honiara.

— 1988b. Provincial Government Review White Paper, Ministry of Home Affairs and Provincial Government, Honiara.

-, 1999a. Western Provincial Headquarters, Gizo: report of the spillover effect and contingency plan, 15-page document, 5 July (Pacific Manuscripts Bureau, 1292).

- 1999b. Report: Provincial Government Review Committee on Provincial Government in Solomon Islands, November, Department of Provincial Government and Rural Development, Honiara (Pacific Manuscripts Bureau, 1292). 
, 2000. A report outlining the views of the provincial governments on the proposed federal government system for Solomon Islands, Provincial Institutional Strengthening and Development Unit, Honiara.

— 2001a. Constitution Amendment (Creation of the Federation) Bill 2001, July, Ministry of Provincial Government and Rural Development, Honiara.

— 2001b. Solomon Islands State Government System Budget, July, Ministry of Provincial Government and Rural Development, Honiara.

- 2002a. Report on the 1999 Population and Housing Census: analysis, Solomon Islands Government, Honiara.

—_, 2002b. Solomon Islands: human development report 2002, Volume 1:building a nation, Main Report, Brisbane.

- 2003. Summary of the provincial community consultation team reports, Government of Solomon Islands and UNDP Constitutional Reform Project, SOI/02/003, Honiara, March.

— , 2004. Draft Federal Constitution of Solomon Islands, 2004, Government of Solomon Islands, Honiara.

Solomon Islands National Archives (SINA), 1913. 'Report, District Officer, Gizo to Resident Commissioner', 10 January 1913, BSIP 21/1/7, Solomon Islands National Archives, Honiara.

Solomon Nius, 1988a. Solomon Nius, 12 February.

— 1988 b. 'Premiers further discuss provincial govt review white paper', Solomon Nius, 22 August.

— 1989a. 'Provincial government to remain says Waena', Solomon Nius, 16 May.

— $1989 \mathrm{~b}$. 'Gov't to devolve more powers to provinces_-Waena', Solomon Nius, 11 August.

Solomon Star, 2000a. 'Premier Lilo appoints new executive govt', Solomon Star, 18 January.

— , 2000b. 'Draft law completed', Solomon Star, 24 January.

—, 2000c. 'Raid of Munda Police Station', Solomon Star, 4 May.

- 2000d. Solomon Star, 14 June.

- 2000e. Solomon Star, 28 June.

— $2000 f$. Solomon Star, 29 June.

- 2000g. Solomon Star, 3 July.

, 2000h. Solomon Star, 11 July.

- 2000i. Solomon Star, 14 July.

- 2000j. Solomon Star, 27 July.

_ 2005. 'PM says federal system in 2006', Solomon Star, 4 March. 
_, 2006. 'Grand coalition pursues adopting new constitution', Solomon Star, 30 May.

Sore, R., Givoro, B. and Ene, E., 2000. Consultancy on State Government Systems: research on the functions of central government systems (Pacific Manuscripts Bureau, 1292).

Spriggs, M., 1992. 'Bougainville update: May to October 1991', in M. Spriggs and D. Denoon (eds), The Bougainville Crisis: 1991 update, Department of Political and Social Change, Research School of Pacific Studies, The Australian National University, Canberra and Crawford House Press, Bathurst:192-5.

Tausinga, J.D., 1987. 'Independence anniversary speech', Sunset News, 7(8), August.

Teutao, R. and Tuhaika, J., 2000. The legal requirements for a change from provincial government system to state government system in Solomon Islands and manpower management in the new state/federal government system (Pacific Manuscripts Bureau, 1292).

Thurnwald, R.C., 1909. 'Reisebericht aus Buin und Kieta', Zeitschrift für Ethnologie, 41.

Tozaka, M., 2000. Provincial government review, Paper presented to the SICHE-ANU Governance and Economics Update conference, 16-17 March, Honiara (Pacific Manuscripts Bureau, 1292).

Western Council, 1975. Submission of the Western Council, Background Paper, No.28, August, Special Committee on Provincial Government, Mimeo. (Pacific Manuscripts Bureau, 1190 as 'SCPG, Background Paper 28 ').

Western Leaders' Consultative Meeting, 2000a. Program, Western Leaders' Consultative Meeting, 3-4 April (Pacific Manuscripts Bureau, 1292).

_ 2000b. A Joint Communiqué by the Leaders of theWestern Province, 4 April 2000, Western Leaders' Consultative Meeting, Gizo (Pacific Manuscripts Bureau, 1292).

- 2000c. Diversity in Unity, Resolution of the Western Leaders' Consultative Meeting, 31 May (Pacific Manuscripts Bureau, 1292).

Western Province Assembly, 2000a. Minutes of the third caucus meeting of Hon. R. Lilo's government, 21-22 March.

—_ 2000b. Western Provincial Assembly: Budget Session 1999/2000, Proceedings of the Western Province Assembly meeting, 25 March-3 April (Pacific Manuscripts Bureau, 1292). 